\title{
Early ontogenesis of the angelfish, Pterophyllum scalare Schultze, 1823 (Cichlidae)
}

\author{
Agata Korzelecka-Orkisz, Zuzanna Szalast, Dorota Pawlos, Izabella Smaruj, \\ Adam Tañski, Joanna Szulc and Krzysztof Formicki
}

This study describes the egg membrane structures of angelfish (Pterophyllum scalare), morpho-physiological changes during angelfish embryogenesis from activation to hatching under optimal conditions $\left(28^{\circ} \mathrm{C} ; \mathrm{pH} 6.8\right)$, the developing larvae and fry, the effect of alkaline $\mathrm{pH}$ on the early developmental stages of the species, the relationship between food item size and fry survival. Egg membranes (thin, transparent, 1.67-2.18 $\mu \mathrm{m}$ thick) are covered by a sticky substance. The amber-coloured angelfish eggs were oval in shape, with average diameters of 1.436 and $1.171 \mathrm{~mm}$, i.e., a mean volume of $1.033 \pm 0.095 \mathrm{~mm}^{3}$. The survival rate of embryos and larvae kept in water with an elevated, slightly alkaline $\mathrm{pH}$ was very low: as few as $2 \%$ of the embryos survived, while in the batch kept in optimal water conditions very few eggs died. The first larvae hatched after $1288 \mathrm{~h}$ of embryonic development. The newly hatched larvae measured on average $2.60 \pm 0.093 \mathrm{~mm}$ and had large $\left(0.64 \pm 0.077 \mathrm{~mm}^{3}\right)$ yolk sacs. They attached themselves to the substrate with a secretion of thin, viscous threads, which was released from glands situated on the top of the head. The glands vanished on day 5. The 1-day-old larvae showed the first pigment cells on the body and the eyes of the 2-dayolds were already fully pigmented. Between day 4 and 5 of larval life, the larvae began feeding on live food. The 23-day-old fry looked like a miniature versions of the adults. Mortality of the angelfish larvae during their first days after hatching was higher in those fed brine shrimp (Artemia salina) nauplii than those fed protozoans and rotifers.

En este trabajo se ha descrito la estructura de las túnicas ovulares del escalar o pez ángel (Pterophyllum scalare), las modificaciones morfo-fisiológicas que transcurren durante la embriogénesis del escalar desde el momento de activización para el desove en condiciones ambientales óptimas $\left(28^{\circ} \mathrm{C} \mathrm{y} \mathrm{pH} 6,8\right)$ y, se han caracterizado las larvas y los alevines desarrollándose. Adicionalmente, se ha estudiado el efecto del $\mathrm{pH}$ básico del agua sobre los primeros estadios de desarrollo y la dependencia entre la cantidad de alimento y la supervivencia de los alevines. Las túnicas ovulares del escalar son finas (1,67-2,18 mm), transparentes, cubiertas de una sustancia viscosa. Los huevos de color ámbar tienen forma ovalada de diámetros medios 1,436 y $1,171 \mathrm{~mm}$ y de un volumen medio de $1,033 \pm 0,095 \mathrm{~mm}^{3}$. El porcentaje de supervivencia de embriones y de larvas en agua con pH aumentado, ligeramente básico, fue muy bajo, ya que sólo el $2 \%$ de los embriones sobrevivió, mientras que en agua de parámetros óptimos sólo algunos huevos palidecieron. Las larvas recién salidas del huevo medían $2,60 \pm 0,093 \mathrm{~mm}$ por término medio y poseían grandes $\left(0,64 \pm 0,077 \mathrm{~mm}^{3}\right)$ sacos vitelinos. Se han adherido al substrato mediante una secreción en forma de filamentos finos y viscosos. Esta secreción se ha desprendido de las glándulas ubicadas en la cumbre de la cabeza. Las glándulas desaparecieron al $5^{\circ}$ día de vida de las larvas. Las larvas de un día poseían ya las primeras células pigmentarias en el cuerpo, los ojos de las larvas de dos días estaban pigmentadas plenamente. Entre el $4^{\circ}$ y $5^{\circ}$ día de vida las larvas empezaron a tomar alimento. Las larvas de 23 días se parecían a una versión miniaturizada de los adultos. La mortalidad de las larvas del escalar alimentadas durante los primeros días a partir del desove con larvas de artemia salina (Artemia salina) fue mayor que la de las alimentadas con protozoarios y rotíferos.

Key words: Egg, Embryogenesis, Embryonic motorics, Larvae morphometry, Membrane structures.

\section{Introduction}

Angelfish occur in the catchment of the Amazon, the world's largest river; they inhabit waters having uniform, albeit specific, chemical and physical conditions (e.g., temperature $27-30^{\circ} \mathrm{C} ; \mathrm{pH} \sim 6.5$ ) in Brazil, Columbia, Peru, Guyana, and French Guyana (Axelrod \& Walker, 2000; Pérez et al., 2003; Abdolbaghian et al., 2010). Angelfish live usually at the depth of 1-2 m, among dense, submerged vegetation (Frank, 1984). Under natural conditions, they grow to $15 \mathrm{~cm}$ total length and $25 \mathrm{~cm}$ total height. The body is strongly flattened dorsoventrally (Mills, 1993).

Angelfish are characterised by specific reproductive behaviour. The territory occupied by the male is of crucial importance: the female chooses a partner based on the specificity of a male's territory, e.g. the plant species growing

Department of Anatomy, Hydrobiology and Biotechnology of Reproduction, the West Po-meranian University of Technology in Szczecin, Poland. Krzysztof.Formicki@zut.edu.pl (KF) 
there, and also the male's body size (Cacho et al., 1999; Chellapa et al., 1999). Prior to spawning, a pair of angelfish cleans a spot they have selected, i.e. wide and flexible leaves or wide and flat stones, whereupon the female lays up to 1000 eggs which are immediately fertilised by the male (Frank, 1984; Sieniawski, 2004; Cacho et al., 2006). The egg-laying is repeated many times, the eggs being released in batches (Sieniawski, 2004). The angelfish eggs are amber-coloured, oval in shape (Groppelli et al., 2003), and contain numerous lipid droplets; the eggs are about 1.46 $\mathrm{mm}$ in diameter (£ugowska, 2007). Both parents care for the eggs, e.g. by guarding them; however, the male takes a lesser role, possibly due to behaviours associated with searching for other females with greater reproductive potential (Cacho et al., 1999). Survival rate of the embryos depends on the male's aggression level. The more aggressive the male, the higher the survival rate of the embryos and larvae. Hence, females choose more aggressive males since it ensures that the effort put into the production of reproductive material is not wasted (Cacho et al., 2006). The level of aggression in males fell at the end of the period of caring for the offspring (Cacho et al., 1999).

Immediately after hatching, the larvae attach themselves with short threads to the substrate and reabsorb the yolk sac material. The threads are secreted by the cement glands (Bennemann \& Pietsch-Rohrschneider, 1978; Groppelli et al., 2003). Once the yolk sac has been reabsorbed, the larvae begin to swim in search for food, but they are still guarded by the parents (Yamamoto et al., 1999; Sarma et al., 2003): movements of the parents' long ventral fins transmit signals that the juveniles respond to (Frank, 1984). While under natural conditions, the parents effectively guard their young and care for them until adulthood, no protective instinct is formed under artificial spawning conditions, resulting in the eggs being eaten by the parents (Kahl et al., 1997). In addition, cannibalism occurs among angelfish in conditions stressful for parents: e.g. it was observed that the eggs might be eaten if parents are continually distressed and forced to leave the reproductive area. Forced loss of contact with the eggs for longer than several minutes results in parents losing their instinct to protect their young, and ultimately eating the entire batch of eggs. It was also observed that the eggs would also be eaten after a failed act of reproduction: for example, if a very small number of eggs have been laid, or when a percentage of eggs have not been fertilised, or when embryogenesis has stopped due to adverse environmental factors. Firstly, the dead eggs are eaten, and if only a few live eggs remain then they too are eaten and the parents prepare for re-spawning. The young can also be threatened by cannibalism from their parents after re-absorption of their yolk sacs: because of limited space in the aquarium, they are not able to move out of the reach of the parents, who start perceiving them as live food. However, there was no cannibalism involving the young eating each other, a characteristic of other species such as Percidae, Siluridae (Smith \& Reay, 1991; Caneppele et al., 2009) or Salminus hilarii (Honji et al., 2011).

Water temperature is an important environmental factor for embryonic development. According to different authors, angelfish prefer temperatures spaning from $27^{\circ} \mathrm{C}$ (Al Adhami \& Kunz, 1976; Axelrod \& Walker, 2000) to $30^{\circ} \mathrm{C}$ (Pérez et al., 2003) to $29-31^{\circ} \mathrm{C}$ (Abdolbaghian et al., 2010). Due to specific environmental conditions (heavy organic enrichment during floods, submerged trees), the Amazon and its tributaries are ionpoor and acidic. Such habitat elicits specific adaptations in organisms, including fish (Val \& Almeida-Val, 1995). Most attention has so far been drawn to the adult fish adaptation mechanisms with respect to low $\mathrm{pH}$. The angelfish are capable of surviving for 3-6 days at $\mathrm{pH} 3.5$, with death occurring as a result of weakened ability to absorb sodium ions. The weakening can be slowed down when the water contains abundant calcium ions (Gonzalez \& Wilson, 2001). So far, however, the effects of water $\mathrm{pH}$ deviating from natural environmental conditions on the angelfish embryonic development have not been analysed.

Although angelfish are frequently kept in aquaria, literature on their reproduction is scant and limited to general descriptions. The present work is the first comprehensive description of egg membrane structures; in addition, morphophysiological changes during the angelfish embryogenesis, from activation to hatching under optimal conditions $\left(28^{\circ} \mathrm{C}\right.$; $\mathrm{pH}$ 6.8) are described, and the developing larvae and fry are characterised. Another task was to find out if slightly alkaline $\mathrm{pH}$ would affect the early developmental stages of the species. Attention was paid to the egg incubation method: embryo survival rates were compared for treatments involving parental care versus incubation in the Weiss apparatus. The relationship between food item size and fry survival was explored. Knowledge of the early stages of angelfish development may prove helpful for practical aspects of fish breeding and enhance breeders' knowledge of the species.

\section{Material and Methods}

The research focused on the developing eggs and the resultant larvae of the angelfish (Pterophyllum scalare). The study was carried out in the aquarium laboratory of the Department of Anatomy, Hydrobiology and Biotechnology of Reproduction from May 2007 to June 2009. Experiments were repeated twice.

Three days before the spawners were released, 80-1 tanks were filled with distilled water. Alder cones (1 cone per 101 water) were placed in the tanks to enrich the water with humic substances and tannins. Thermostats kept the water temperature constant $\left(28 \pm 0.2^{\circ} \mathrm{C}\right)$. The tanks were illuminated with incandescent lamps switched on for 12 hours a day. During the experimental period all water quality parameters were kept constants and monitored constantly using multimeter CX-401 (Elmetron).

Mature, ready to spawn pairs of future parents were released into the tanks already containing a substrate in the form of black strips of plastic, hung vertically. In experimental treatments $1 \mathrm{a}$ and $1 \mathrm{~b}$, the eggs laid on the substrate were guarded by the parental fish which refreshed the water around the eggs by fanning their fins and removing dead eggs. In treatment $2 \mathrm{a}$ and $2 \mathrm{~b}$, immediately after they were activated, 
the eggs were transferred, together with the substratum to which they were attached, to small PET Weiss jars placed in a 60-1 tank (Table 1). The aerated water flowing upwards through the jar rinsed the substrate with the eggs and rolled down the jar walls in a gentle stream. The water in each tank was kept at a constant temperature $\left(28 \pm 0.2^{\circ} \mathrm{C}\right)$, with appropriate oxygen conditions being ensured by continuous aeration.

Embryogenesis was monitored at $28^{\circ} \mathrm{C}$ and at two $\mathrm{pH}$ levels (6.8 and 8.2) (Table 1). For each experimental treatment, the embryo survival rate was calculated at the moment of hatching. $\mathrm{h}$ - sum of temperature in ${ }^{\circ} \mathrm{C}$ in successive hours.

The egg membranes were examined under a FEI Quanta 200 scanning electron microscope (SEM). The eggs were fixed in buffered $4 \%$ formaldehyde and then dehydrated in alcohol series and in acetone. Subsequently, the eggs were dried using liquid $\mathrm{CO}_{2}$ at the so-called critical point, mounted on bases, and dusted with a thin layer of gold-palladium alloy. Diameters $\left(d_{1}, d_{2}\right)$ of yolk spheres and eggs were measured using NIS Elements software, and used to calculate volumes $\left(\mathrm{V}=1 / 6 * \Pi * \mathrm{~d}_{1} * \mathrm{~d}_{2}{ }^{2}\right)$. Observation and recording of the angelfish embryonic and larval development were carried out using two sets of equipment:

- Nikon TE-2000S microscope, Sony CCD digital camera equipped with a monitor and S-VHS recorder, computer (with the NIS Elements software);

- SMZ 1500 stereomicroscope with a Trol-8100/9100 microprocessor regulator and a Nikon DS. Fi-1 digital colour camera equipped with a monitor.

When examining the larvae, their total body length (longitudo totalis, 1.t.), length (1) and height (h) of the yolk sac were measured. The yolk sac volume was calculated using the formula: $V=1 / 6 * \Pi * 1 * h^{2}\left[\mathrm{~mm}^{3}\right]$. On their second day after hatching, the larvae were transferred to another 60-litre container in which they were kept in water of temperature 28 $\pm 0.2^{\circ} \mathrm{C}, \mathrm{pH} 7.5$, and $1 \mathrm{GH}$ hardness. The total larval length was measured daily; measurements were taken also of the developing fins; in addition, the development of internal organs was analysed. The larval survival rate in each experimental treatment was calculated.

The larvae were fed three times a day from the $4^{\text {th }}$ day after hatching. The larvae were divided into two groups (each sample analysed consedered of 50 specimens). Those in the first group were fed brine shrimp nauplii (Artemia salina). The second group larvae were fed protozoans and rotifers for the first two days, with brine shrimp nauplii being added to the diet on the third day. The larval mortality was calculated in each treatment. Experiments were repeated twice.

The results obtained were processed using Statistica 9.0 PL: Shapiro-Wilk normality test was used for size distribution the eggs and yolk spheres of angelfish and Duncan's multiple test for survival rate of embryos and larvae.

\section{Results}

Egg membranes. The egg membranes (thin, transparent, 1.67$2.18 \mu \mathrm{m}$ thick, Fig. 1A) were covered by a substance which
Table 1. Experimental treatments.

\begin{tabular}{|c|c|c|c|c|}
\hline \multirow{5}{*}{$\begin{array}{l}\text { Water parameters } \\
\text { Temperature }\left[{ }^{\circ} \mathrm{C}\right] \\
\text { pH }\end{array}$} & \multicolumn{4}{|c|}{ Experimental treatments } \\
\hline & $1 \mathrm{a}$ & $1 \mathrm{~b}$ & $2 \mathrm{a}$ & $2 \mathrm{~b}$ \\
\hline & \multicolumn{2}{|c|}{$\begin{array}{l}\text { eggs guarded by } \\
\text { parental fish }\end{array}$} & \multicolumn{2}{|c|}{$\begin{array}{l}\text { eggs incubated in } \\
\text { Weiss jars }\end{array}$} \\
\hline & 28 & 28 & 28 & 28 \\
\hline & 6.8 & 8.2 & 6.8 & 8.2 \\
\hline
\end{tabular}

was sticky for the first few seconds after the egg is released into the water. When detached from the substratum, the eggs showed no tendency towards re-attachment either to the substrate or to other eggs. The egg membrane was porous on the inside, although individual pores were very small. The outer surface was also perforated by small pores. The presence of some bacteria was observed (Fig. 1B).

Eggs and yolk spheres. The amber-coloured angelfish eggs were oval in shape, with average diameters of $1.44\left(\mathrm{~d}_{1}\right)$ and $1.17 \mathrm{~mm}\left(\mathrm{~d}_{2}\right.$ ), i.e., a mean volume of $1.03 \pm 0.095 \mathrm{~mm}^{3}$ (Fig. 2). The yolk sphere inside measured, on average, $1.19\left(\mathrm{~d}_{1}\right)$ and $1.09 \mathrm{~mm}\left(\mathrm{~d}_{2}\right)$, i.e. had an average volume of $0.74 \mathrm{~mm}^{3}$ (Fig. 3). The size variability between either yolk spheres or eggs was not large, as the difference between the smallest and the largest amounted to about $60 \%$ (Table 2). The perivitelline space was not large, being on average $28 \%$ of the egg volume. The yolk sphere showed very numerous fine droplets of structural lipids, scattered throughout the sphere. During embryonic development, the droplets became scattered at first in the layer of the yolk sphere, and later in the yolk contained in the yolk sac.

Embryogenesis. After about 20 minutes $\left(9.3 \mathrm{~h}^{\circ}\right)$ from fertilisation, ectoplasm accumulation ceased and the reception mound developed (Fig. 4A). The reception mound transformed into the germ disc. The process always occurred on the same side as the yolk sphere, because that was where there was free space.

Cleavage. Soon after fertilisation, the germ plate began to divide into blastomeres. The first cleavage furrow (2 blastomeres) appeared after 45 minutes $(21 \mathrm{~h})$ from fertilisation. The subsequent furrow that divides each blastomere into two parts appeared $1 \mathrm{~h}(28 \mathrm{~h})$ after egg activation and produced 4 blastomeres (Table 3 ). The third furrow (8 blastomeres) appeared $1 \mathrm{~h} 15$ minutes $(35 \mathrm{~h})$ after fertilization (Fig. 4B). The fourth furrow (16 blastomeres) became visible after $1 \mathrm{~h} 47$ minutes $(41.3 \mathrm{~h})$. Subsequent divisions increased the number of blastomeres. Eventually, 4 hours $(112 \mathrm{~h})$ after fertilization, the small-celled blastula developed (Table 3).

Gastrulation. Gastrulation began after $239 \mathrm{~h}$; after $420 \mathrm{~h}$ the eggs were at the stage of half-epiboly. After 21 hours from fertilisation (588 h), $3 / 4$ epiboly was visible, as was the outline of the embryo's body (Fig. 4C). Gastrulation terminated when the entire yolk was covered by cells (which happened after 616 h) (Table 3). 

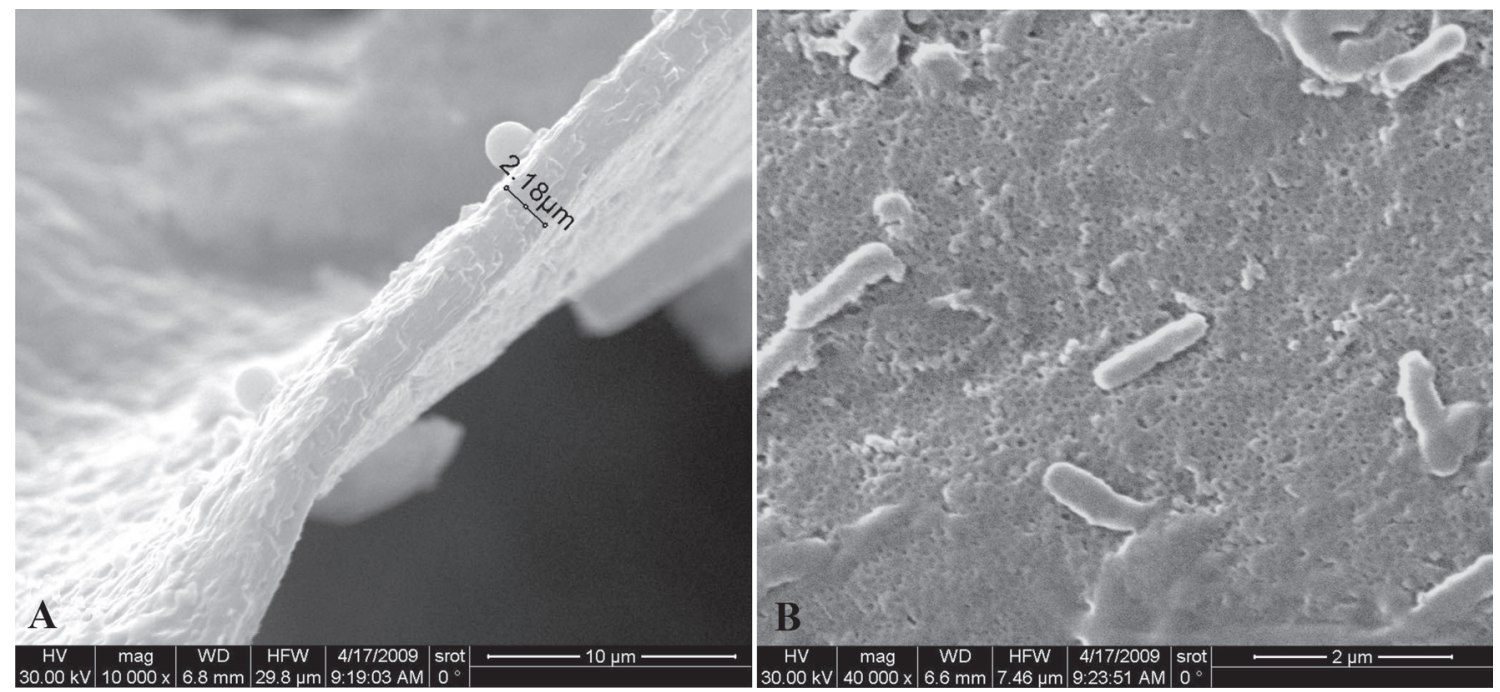

Fig. 1. SEM micrographs of the egg membrane of the angelfish Pterophyllum scalare. A) Cross-section of egg membrane (10 $000 \times)$, B) Outer surface of egg membrane $(40000 \times)$.

Organogenesis. Once gastrulation had terminated, the embryo's head began to increase and protrude above the yolk sac surface. The first somites appeared in the embryo's body (Fig. 4D), initially in the trunk part, at 26 hours after fertilisation ( $729.5 \mathrm{~h}$ ) (Table 3$)$. The embryo's heart became active in hour 33 (924 h) of the embryonic development; the contraction rhythm, initially slow, accelerated rapidly to reach 94 beats per minute in hour $34(952$ h). The beginning of the cardiac muscle contractions was swiftly followed by movements of the whole body. Initially, the movements involved slight, but frequent, contractions of the trunk ( 1 contraction per minute). Over time, the contractions became more extensive and less frequent, but stronger and performed in series. Immediately prior to hatching (Fig. 5), a rate of 15 contractions per minute were observed. The heart rate, regular until the moment of hatching, increased to reach 130 beats per minute at $1288 \mathrm{~h}$. The survival rate of embryos and larvae kept in water with elevated, slightly alkaline $\mathrm{pH}$ was very

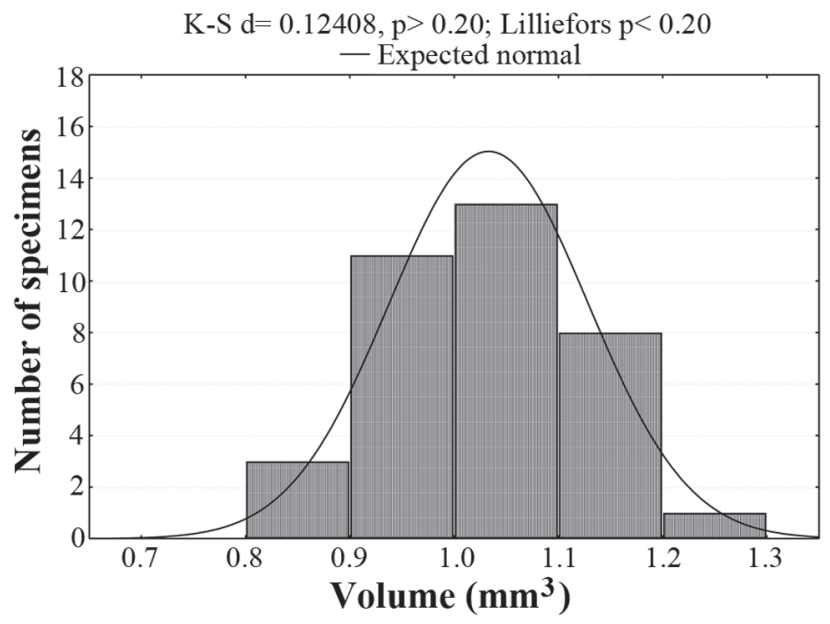

Fig. 2. Volume distribution in eggs of Pterophyllum scalare. low: as few as $2 \%$ of the embryos survived, while very few eggs died in the batch kept in water of optimal parameters (Table 4).

Hatching. The first larvae hatched at $1288 \mathrm{~h}$ of the embryonic development (Table 3). They always left the egg membranes tailfirst; no other way of hatching was observed. The appearance of the larval tail was a signal for the parents to help the larva to leave the egg. A female then took the hatching egg into her mouth and spit the larvae onto the spawning substrate a number of times until the larva produced threads and attached itself. If the larva failed to do that, it was taken by the female again. So the spitting process was repeated by the female until a sticky thread appeared on the larva's head. The newly hatched larvae measured, on the average, $2.60 \pm 0.093 \mathrm{~mm}$ and had large yolk sacs $\left(0.64 \pm 0.077^{3}\right)$ (Fig. 6A). On leaving the egg, the larvae showed no eye pigment. They attached themselves to the substrate by secreting thin, sticky threads. Usually a single thread

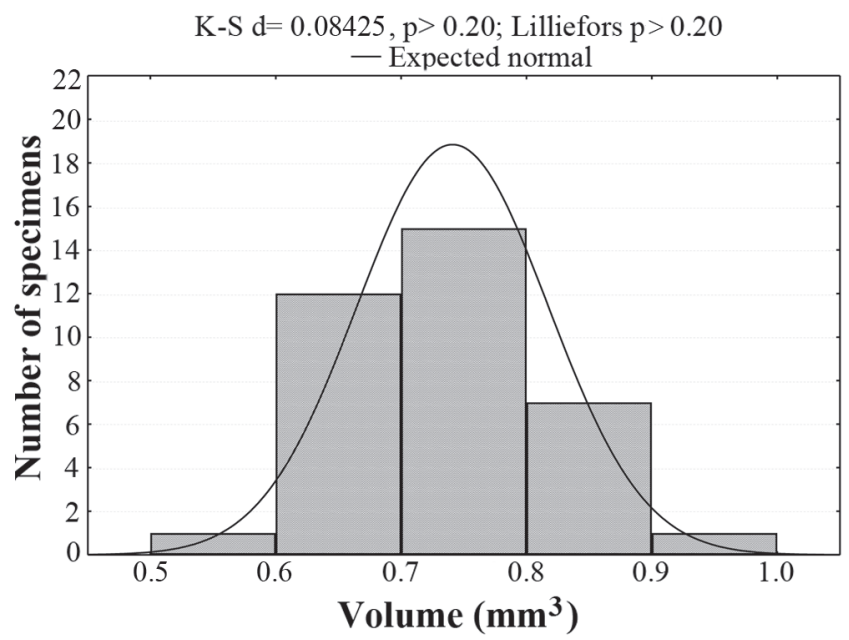

Fig. 3. Volume distribution in yolk spheres of Pterophyllum scalare. 
Table 2. Size of angelfish (Pterophyllum scalare) eggs and yolk sphere $\left(\mathrm{n}=60 ; \mathrm{d}_{1}, \mathrm{~d}_{2}=\right.$ diameters; $\overline{\mathrm{x}} \pm \mathrm{sd}=$ mean and standard deviation).

\begin{tabular}{|c|c|c|c|c|c|c|c|}
\hline & \multicolumn{4}{|c|}{ Diameter [mm] } & \multicolumn{2}{|c|}{ Volume $\left[\mathrm{mm}^{3}\right]$} & \multirow{3}{*}{$\begin{array}{c}\text { Perivitelline } \\
\text { space [\%] }\end{array}$} \\
\hline & \multicolumn{2}{|c|}{ Egg } & \multicolumn{2}{|c|}{ Yolk sphere } & \multirow{2}{*}{ Egg } & \multirow{2}{*}{ Yolk sphere } & \\
\hline & $\mathrm{d}_{1}$ & $\mathrm{~d}_{2}$ & $\mathrm{~d}_{1}$ & $\mathrm{~d}_{2}$ & & & \\
\hline \multirow{3}{*}{$\begin{array}{c}\bar{x} \pm \mathrm{sd} \\
\min . \\
\max .\end{array}$} & $1.44 \pm 0.05$ & $1.17 \pm 0.05$ & $1.19 \pm 0.07$ & $1.09 \pm 0.04$ & $1.03 \pm 0.09$ & $0.74 \pm 0.08$ & $28.09 \pm 5.96$ \\
\hline & 1.37 & 1.05 & 1.09 & 1.01 & 0.81 & 0.59 & 14.92 \\
\hline & 1.59 & 1.28 & 1.36 & 1.18 & 1.23 & 0.92 & 39.64 \\
\hline
\end{tabular}

to the substrate, the larvae moved vigorously and never remained motionless, until they tore free of the substrate.

Development of larvae and fry. The larvae remained attached to the substrate for four days. On day 5, when the glands producing viscous threads disappeared and the yolk sac was almost completely reabsorbed, the larvae began to descend to the bottom of the tanks. It was then that the larvae made their first attempts at swimming and began searching for food. The first pigment cells were observed on the body of 1-day-old larvae, but no eye pigment was observed. By day 2 of larval life, their eyes were already fully pigmented. On day 3 of the
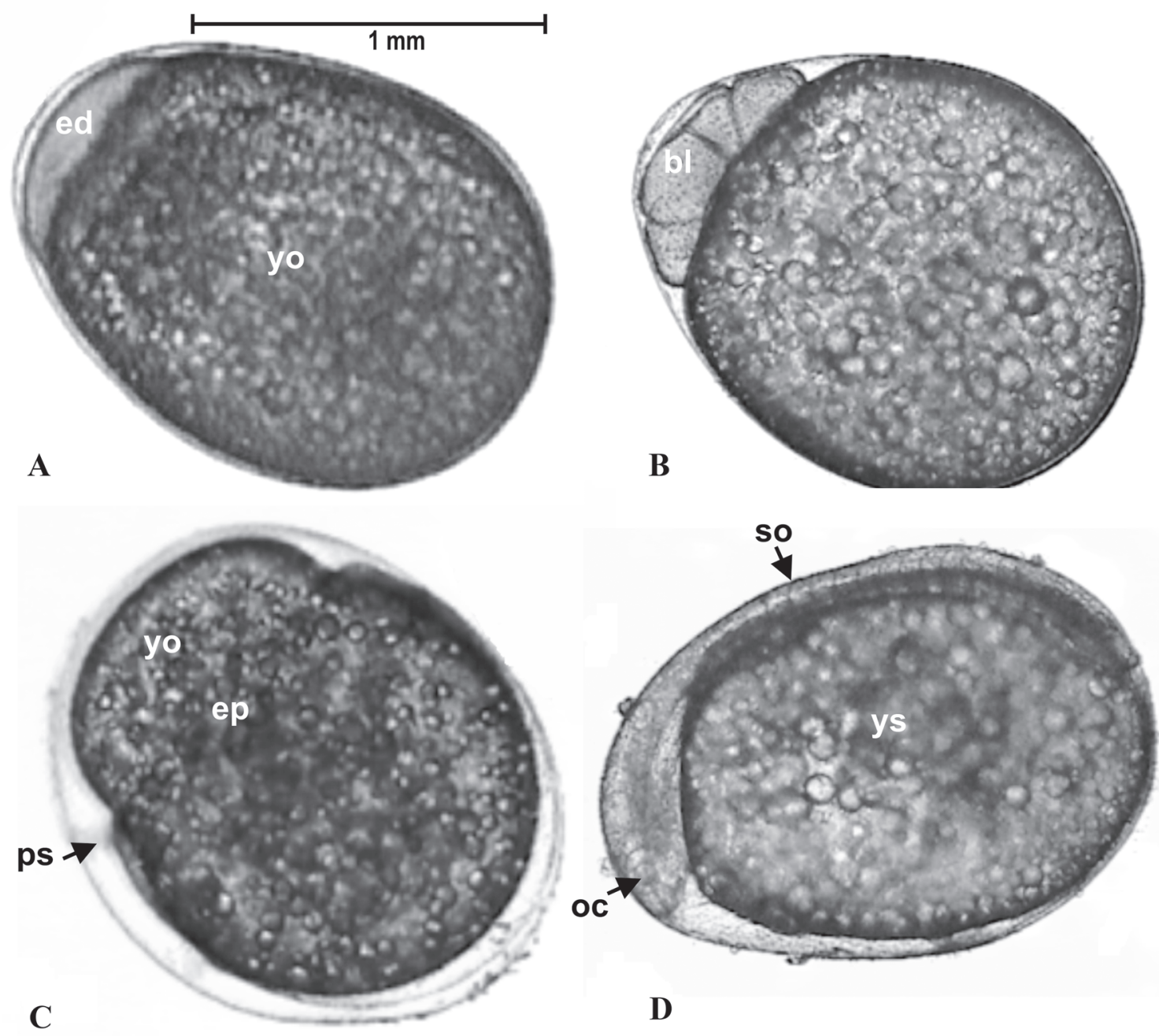

D

Fig. 4. Stages of embryonic development of Pterophyllum scalare. A) Formation of perivitelline space after water absorption and concentration of maternal cell material at the animal pole $20 \mathrm{~min}$ after fertilisation (ed - embryonic disc, yo - yolk sphere); B) 8-blastomere stage (bl - blastomere); C) 80-85\% epiboly with the blastopore wide open. The yolk-sac syncytium shows still lapping cells at the fringes (yo - yolk sphere, ps - perivitelline space, ep - epiboly); D) Development of the cephalic part; the somites are well developed along the latter part of the body axis but not fully reached the frontal region; the optic capsule is vaguely visible and the eye capsules are not yet completed (so - somites, oc - optic capsule, ys - yolk sac). 
was produced, although two to four were occasionally observed. The secretion was released from glands situated on the top of the head (Fig. 6B). Usually, there were two pairs of glands visible until day 4 of larval life, i.e. until the yolk sac was reabsorbed (Fig. 7A). The glands vanished on day 5 (Fig. 7B). When attached larval life, the egg sacs were half-reabsorbed (Fig. 7A), and reabsorption was completed between day 4 and 5. At this stage, the larvae began feeding on live food, the brine shrimp nauplii (A. salina). Most of the 5-day-old larvae showed the presence of a swim bladder chamber (Fig. 7B). The 6-day-old larvae doubled their length (Table 5), their yolk sacs were completely reabsorbed, and their intestinal loops were visible. In 1-weekold larvae, the dorsal and anal fins began to differentiate from the skin fold (Fig. 7C). The skin fold began to disappear on day 8 . The dorsal fin showed the first ray to emerge, and primordial ventral fins were observed (Table 5). In the 10-day-old larvae, the skin fold surrounding the posterior part of the body was just discernible. The first rays appeared on the anal fins and the ventral fins appeared (Table 5). All the fins were differentiated on the12-day-old fry. From that day on, a rapid growth rate was observed. On day 16 , the swim bladders all the fish were seen to consist of two chambers. In the 18-day-old fry, the dorsal fin rays 12-20 and the anal fin rays 6-10 began to elongate, which is a species-specific character. On day 20, a few fry $(4 \%)$ failed to have developed the swim bladder and their growth stopped; the affected fry had problems with swimming. On day 22, the kidneys and gills were welldeveloped. The 23-day-old fry showed well-developed opercula, skull bones, jaws, and backbones. The 25-day-old fry looked like miniature versions of the adults (Fig. 7D-7F).

Larval feeding. Mortality of the angelfish larvae (group 1) fed brine shrimp (A. salina) nauplii was higher than of those fed protozoans and rotifers during their first days of life posthatching. At the beginning, it was difficult for the angelfish larvae to take up larger organisms such as the brine shrimp

Table 3. Embryogenesis and characteristics of angelfish (Pterophyllum scalare) larvae.

\begin{tabular}{lr}
\hline \multicolumn{2}{c}{ Embryogenesis } \\
\hline 2 blastomeres & $21 \mathrm{~h}$ \\
4 blastomeres & $28 \mathrm{~h}$ \\
8 blastomeres & $35 \mathrm{~h}$ \\
16 blastomeres & $41.3 \mathrm{~h}$ \\
Fine blastomere blastula & $112 \mathrm{~h}$ \\
1/2 Epiboly & $420 \mathrm{~h}$ \\
3/4 Epiboly & $588 \mathrm{~h}$ \\
Embryo's body outline, blastopore closure & $616 \mathrm{~h}$ \\
First somites & $729.5 \mathrm{~h}$ \\
Budding heart contractions & $924 \mathrm{~h}$ \\
First movements of embryo's trunk and tail & $980 \mathrm{~h}$ \\
\hline \multicolumn{2}{c}{ Hatching of larvae } \\
\hline First hatch Characteristics of newly hatched larvae \\
50\% hatch \\
Last hatch \\
\hline \multicolumn{2}{c}{2.60} \\
\hline Body length (mm) & $1288 \mathrm{~h}$ \\
Yolk sac volume (mm $\left.{ }^{3}\right)$ & $1344 \mathrm{~h}$ \\
\hline
\end{tabular}

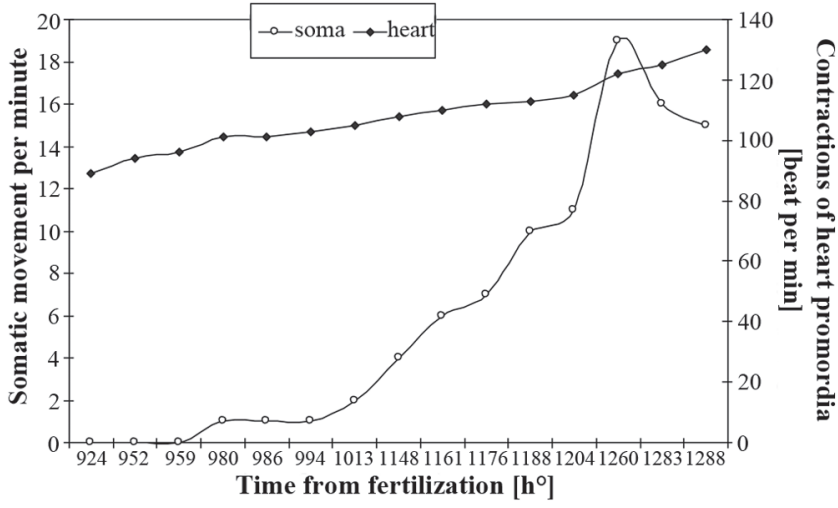

Fig. 5. Somatic and cardiac movements of angelfish during embryonic development.

nauplii which measure about $0.7 \mathrm{~mm}$ in length and about 0.6 $\mathrm{mm}$ in width (at the head level and with antennae spread out); the angelfish mouth, when gaping, is as small as $0.4 \mathrm{~mm}$ across (Fig. 8). The mortality rate during the first four days since feeding began was $8 \%$. On the other hand, those larvae (group 2) fed protozoans and rotifers during the first two days, with brine shrimp nauplii added to the diet subsequently, grew better and had a lower mortality rate (3\%).

\section{Discussion}

The data and observations collected in this study supplied new information on reproduction and morphophysiological changes taking place during embryonic and larval development of the angelfish (P. scalare).

Cichlid eggs are, as a rule, oval in shape, like in other fish species with large genital papillae, e.g. algae eaters such as the bushymouth catfish, Ancistrus dolichopterus, or with an ovipositor, such as the bitterling, Rhodeus sericeus (cf. Aldridge, 1999), although egg dimensions (length, width, diameter) are species-specific. The ovipositor makes it possible for the female to precisely position one egg after another in a row at a place she chooses. The ellipsoid shape of the egg allows many eggs to be laid in a small area, which facilitates parental brood care. This close "packing" of the eggs is made feasible by the very intensive care given by the parents, who

Table 4. Effects of water parameters on per cent survival rate of embryos and larvae; values denoted with different number of asterisks are significantly different; Duncan's multiple test $(\mathrm{P}<0.05)$

\begin{tabular}{lcccc}
\hline & \multicolumn{4}{c}{ Experimental treatments } \\
\cline { 2 - 5 } & \multicolumn{1}{c}{$1 \mathrm{a}$} & $1 \mathrm{~b}$ & $1 \mathrm{a}$ & $2 \mathrm{~b}$ \\
\cline { 2 - 5 } & \multicolumn{2}{c}{$\begin{array}{c}\text { eggs guarded by } \\
\text { parental fish }\end{array}$} & \multicolumn{2}{c}{$\begin{array}{c}\text { eggs incubated } \\
\text { in Weiss jars }\end{array}$} \\
\hline $\mathrm{pH}$ & 6.8 & 8.2 & 6.8 & 8.2 \\
$\%$ survival rate of embryos & $98.0^{*}$ & $2.0^{* *}$ & $99.8^{*}$ & $0 * *$ \\
\% survival rate of larvae & $98.5^{*}$ & $62.0^{* *}$ & $99.0^{*}$ & $0 * * *$ \\
younger than 10 days & & & & \\
\hline
\end{tabular}




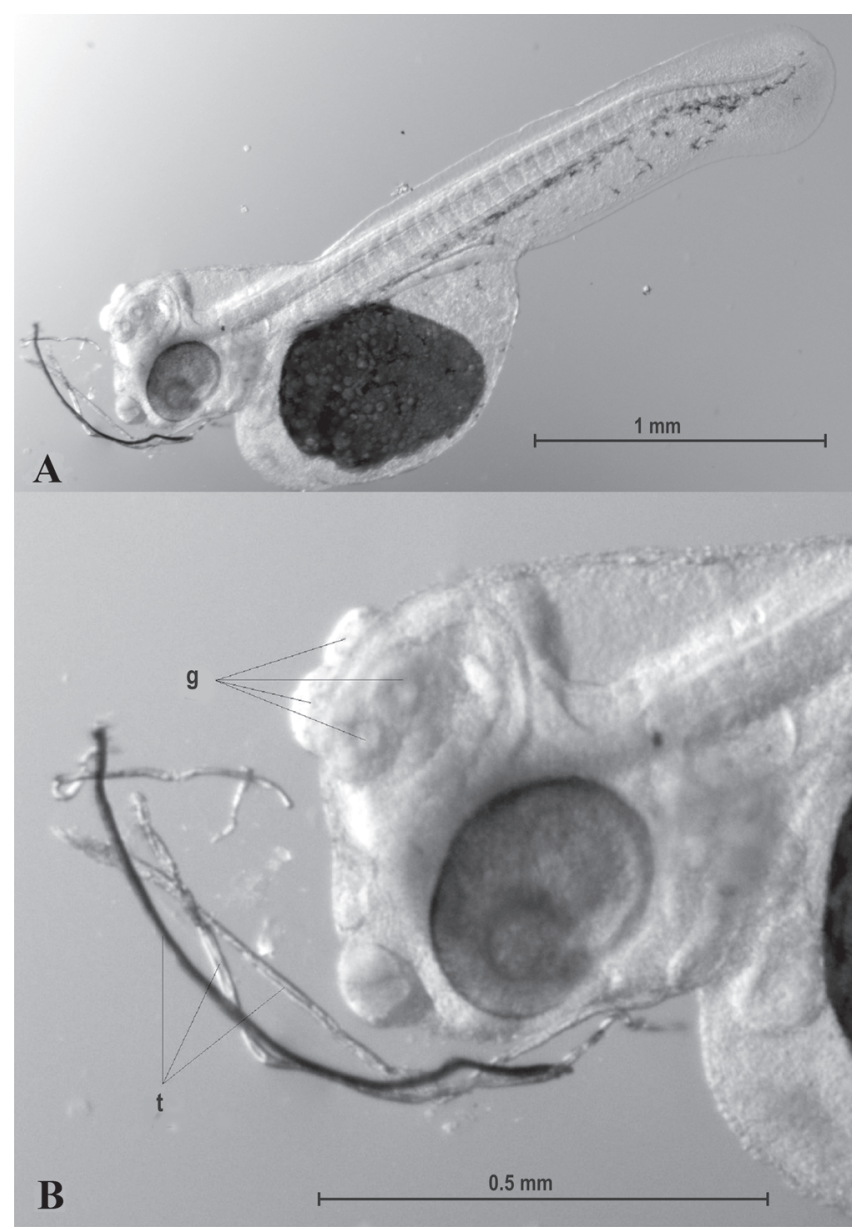

Fig. 6. A) A newly hatched larva of angelfish; B) Anterior part of a individual with the threads $(t)$ secreted by the cement glands (g).

not only protect the eggs, but also force the flow of water between the eggs, making it easier for oxygen to reach the surface of the tract of each embryo. The angelfish eggs are small, their volume being similar to that of blue discus (Symphysodon aequifasciatus) eggs (cf. Coleman, 2002). The eggs are the smallest of all the cichlids. They are 5 times smaller than those of Theraps irregulare and 8 times smaller than those of the Thorichthys tuba (Coleman, 2002; Froese \& Pauly, 2010).

The egg membrane lacks projections or other club-shaped structures typical of, e.g. cyprinids, which also attach their eggs to the substrate (Riehl \& Appelbaum, 1991; Szulc, 2007). Such projections present on the eggs of white bream, vimba or shorthorn sculpin (Szulc, 2007) play a very important role, apart from attaching the egg to the substrate, because they facilitate the water flow between the egg and the substrate, so that the water can rinse the entire egg surface and thus ensure gas exchange. The smooth surface of angelfish eggs is most probably associated with the parent fish aerating them by forcing the water flow. The behaviour was successful in the angelfish, so that elimination of a part of the surface through which oxygen could penetrate the egg did not adversely affect the oxygen conditions to which the developing embryo is exposed.

It is also interesting that the sticky substance is present on the egg surface for a short time only. A similar phenomenon was reported from some other fish species, e.g. stinging catfish (Heteropneustes fossilis) (Korzelecka et al., 2010). The sticky substance is necessary only for attaching the egg to the substrate; should it have remained on the egg surface, it would have restricted oxygen diffusion into the egg. Besides, such a substance is an excellent medium for bacteria, the abundance of which significantly slows down the rate of embryonic development.

Parental care considerably enhances survival rate of the hatchlings and the quality of embryonic development. Throughout the egg incubation stage, the parent fish ensure that the rapidly developing embryos receive constant oxygen supply by fanning their fins (Reebs, 2001). The thin egg membranes provide no particular obstacle for gas exchange. For this reason, the embryos develop with a perivitelline space which is relatively small (about $30 \%$ ), compared to that in, e.g. cyprinids such as tench, rudd, bleak, the eggs of which show $70 \%$ of the volume being taken by the perivitelline space (Winnicki \& Korzelecka, 1997; Korzelecka \& Winnicki, 1998; Bonislawska et al., 1999). Despite the relatively small perivitelline space, the angelfish show no quasi-peristaltic movements of the ectoplasm similar to those reported in pike (Tañski et al., 2000) or stickleback (Winnicki et al., 1998); in those species, there is an ectoplasm wave movement along the yolk sphere surface, which mixes the perivitelline space and effectively enhances oxygen transport to the respiratory surfaces of the embryo (Bonislawska et al., 1999; Formicki et al., 2009). Regular aeration of water at the egg surface, brought about by the parental fish fin movement, ensures that despite high ambient temperature, the embryos receive a sufficient oxygen supply; a quasi-peristaltic movement would in this membrane seem an unnecessary loss of energy.

It is fairly common for newly hatched fish larvae to attach themselves to a substrate and to remain attached until the yolk sac is reabsorbed. The angelfish larvae attach themselves with a secretion from glands located on the head, and remain attached until the yolk sac is reabsorbed. Attachment prevents the larvae from being moved into the water column where, not guarded by the parents, they could become an easy prey for predators. In fish species with no brood care, e.g., pike (Tañski et al., 2000) or tench (Korzelecka et al., 2009), larval attachment to submerged plants is a means to avoid predators by blending into the surroundings and also a way to prevent sinking down to the bottom, where the oxygen conditions are usually far from appropriate. The angelfish take a good care of both their eggs and larvae; exercising that care is facilitated by larval attachment to the substrate. In addition to protection from predators which the parents provide, the fanning movement of parental fins aerates the water around the larvae, thus improving the oxygen conditions for them (Barlow, 1991; Meijide \& Guerrero 2000). Noteworthy are the rapid movements of the larvae, which are important for two reasons. On the one hand, they aerate the water surrounding the yolk sac, and as blood vessels lie on the surface of the yolk sac, 


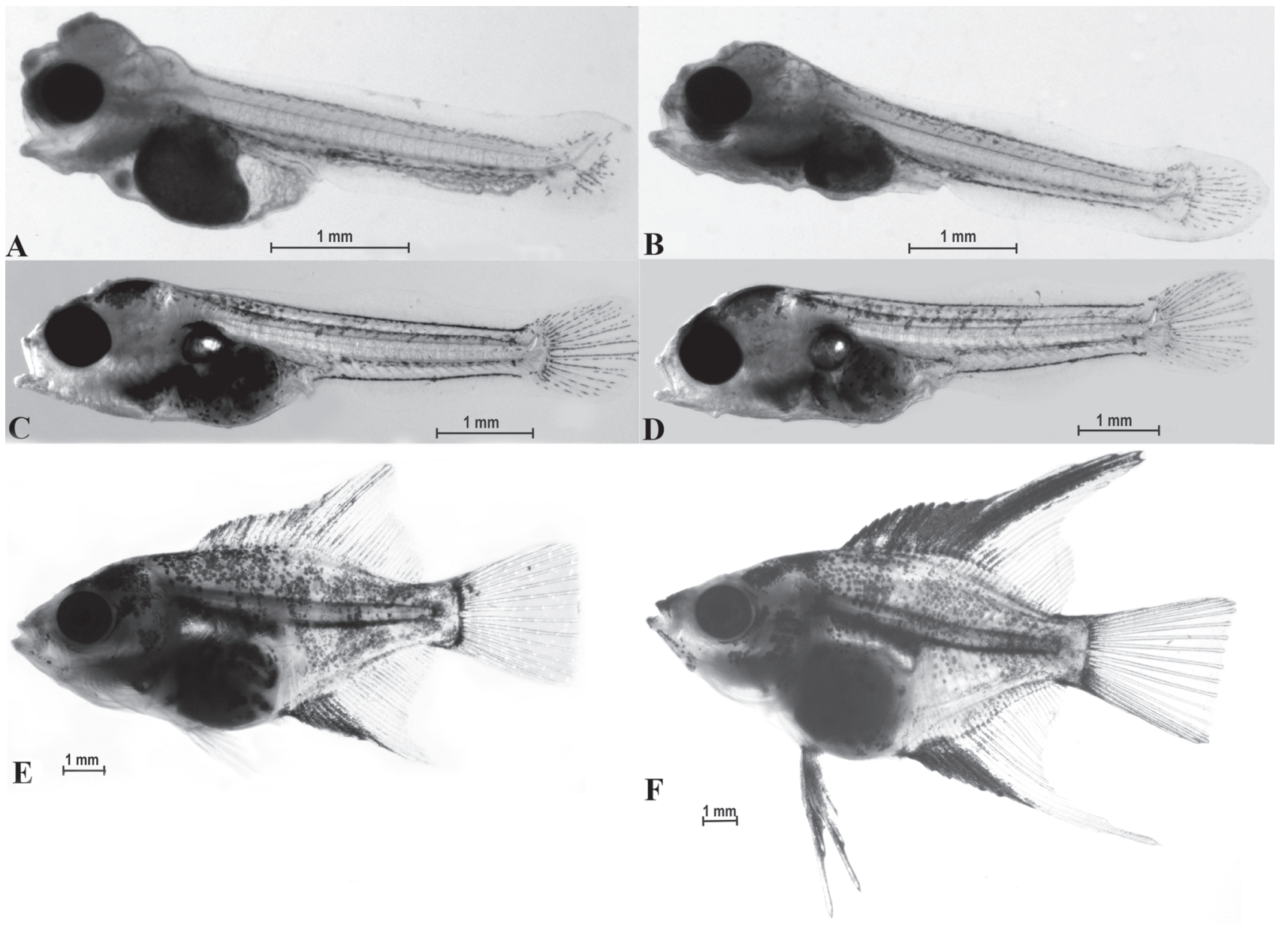

Fig. 7. Larvae of Pterophyllum scalare. A) The 3-days-old larva, reabsorption of the yolk sac in a larva, the movable mandible, open alimentary canal; B) The 5-days-old larva - content of yolk sac reabsorbed, development of arches and gill filaments; C) The 7-days-old larva - reduction of the fold surrounding the larvae and separation of the caudal part, visible loops of the intestine, increasing number of melanophore in the cephalic part, the visible swim bladder; D) The 10-days-old larva - the skin fold surrounding the posterior part of the body almost disappeared, in the anal fin first rays well developed, beginning of abdominal fins; E) The 14-days-old larva - elongating rays in the dorsal fin and anal fin; F) The 23-days-old larva - body shape and proportions similar as at adult individuals.

oxygen diffusion into the circulatory system is enhanced. On the other hand, the movements allow the larvae to continue flexing their muscles, which had started at the embryonic phase; the well-exercised muscles allow the larvae to rapidly swim back to the parent fish when threatened.

The swim bladder was observed to be lacking in $4 \%$ of the fry. This resulted in growth retardation, although the fish were observed to feed. They also had some problems with swimming. Most probably, the swim bladder had failed to develop as a result of localised surface tension, which prevented the larvae from inhaling a portion of air which has to be pushed into the budding swim bladder at a fixed time during development so that it can develop at all. A similar occurrence was reported from other percids (perch, zander) (Barrows et al., 1993). Changes taking place during development result in the atrophy of the pneumatic duct (ductus pneumaticus) through which the air, inhaled from above the water surface, should be pushed in. Initiation of this process is important for further development to be regular and for the larvae to survive.

As shown by our study, artificial breeding has to be carried out with a consideration of the characteristics of the waters of the species' natural habitat. The high amount of organic matter in the Amazon, including silt particles, humic acids and tannins reduces water $\mathrm{pH}$ which is 6.9 in the upstream Amazon, and drops down to as low as 3.8 locally in Amazon tributaries (the "black rivers": rio Negro, rio Cururu and rio Icana) (Zalachowski, 1997). Fish living in the Amazon have adapted to specific environmental conditions by developing respiratory organs in the form of true lungs as in Lepidosiren paradox, modifying the swim blender as in Arapaima gigas, or through enriching the vascularity of the oral cavity as in Electrophorus electricus (Brauner \& Val, 1996). Additionally, Amazon fish have adaptive mechanisms that enable them change the level of oxygen in the blood by increasing ventilatory frequency and volume, heart rate, increasing 
Table 5. Growth of larvae and fry and fin development $[\mathrm{n}=60]$, $\mathrm{pH}=6.8$

\begin{tabular}{|c|c|c|c|c|c|}
\hline $\begin{array}{c}\text { Day of } \\
\text { life }\end{array}$ & $\begin{array}{c}\text { Body } \\
\text { Length } \\
{[\mathrm{mm}]}\end{array}$ & $\begin{array}{c}\text { Dorsal fin } \\
\text { height } \\
{[\mathrm{mm}]}\end{array}$ & $\begin{array}{c}\text { Anal fin } \\
\text { height } \\
{[\mathrm{mm}]}\end{array}$ & $\begin{array}{c}\text { Tail } \\
\text { Length } \\
{[\mathrm{mm}]}\end{array}$ & $\begin{array}{c}\text { Ventral fins } \\
\text { length } \\
{[\mathrm{mm}]}\end{array}$ \\
\hline 0 & 2.6 & & & 0.1 & \\
\hline 1 & 4.2 & & & 0.1 & \\
\hline 2 & 4.5 & & & 0.1 & \\
\hline 3 & 4.7 & & & 0.2 & \\
\hline 4 & 5.0 & & & 0.4 & \\
\hline 5 & 5.5 & & & 0.6 & \\
\hline 6 & 5.7 & & & 0.8 & \\
\hline 7 & 6.5 & & & 1.0 & \\
\hline 8 & 6.7 & 0.4 & 0.4 & 1.2 & \\
\hline 10 & 6.9 & 0.5 & 0.5 & 1.4 & 0.1 \\
\hline 12 & 8.3 & 0.6 & 0.6 & 1.5 & 0.2 \\
\hline 14 & 10.0 & 0.8 & 0.8 & 2.0 & 0.3 \\
\hline 16 & 12.0 & 1.7 & 1.7 & 2.5 & 1.2 \\
\hline 18 & 14.0 & 3.2 & 3.2 & 3.0 & 2.0 \\
\hline 20 & 15.0 & 4.2 & 4.2 & 3.4 & 2.2 \\
\hline 22 & 16.0 & 5.2 & 5.2 & 3.8 & 2.5 \\
\hline 23 & 17.5 & 6.5 & 6.5 & 4.0 & 4.1 \\
\hline 25 & 18.0 & 7.0 & 7.0 & 4.3 & 4.5 \\
\hline
\end{tabular}

numbers of circulating erythrocytes, raising haemoglobin concentration, increasing hemetocrit, intensifying haemoglobin oxygen affinity and depressing metabolism (Val \& Almeida-Val, 1995). Such numerous, specific adaptations start to be activated at the stage of early ontogeny. While adult fish are able to adapt to unusual environmental conditions over time (e.g., slightly alkaline water $\mathrm{pH}$ ) and enter spawning mode, juvenile organisms growing under conditions unusual for them are not able to survive.

Therefore slightly alkaline water ( $\mathrm{pH} 8.2$ ), of a $\mathrm{pH}$ different to that found in the natural habitat (acidic to slightly acidic) becomes lethal to the embryos (Axelrod \& Walker, 2000).

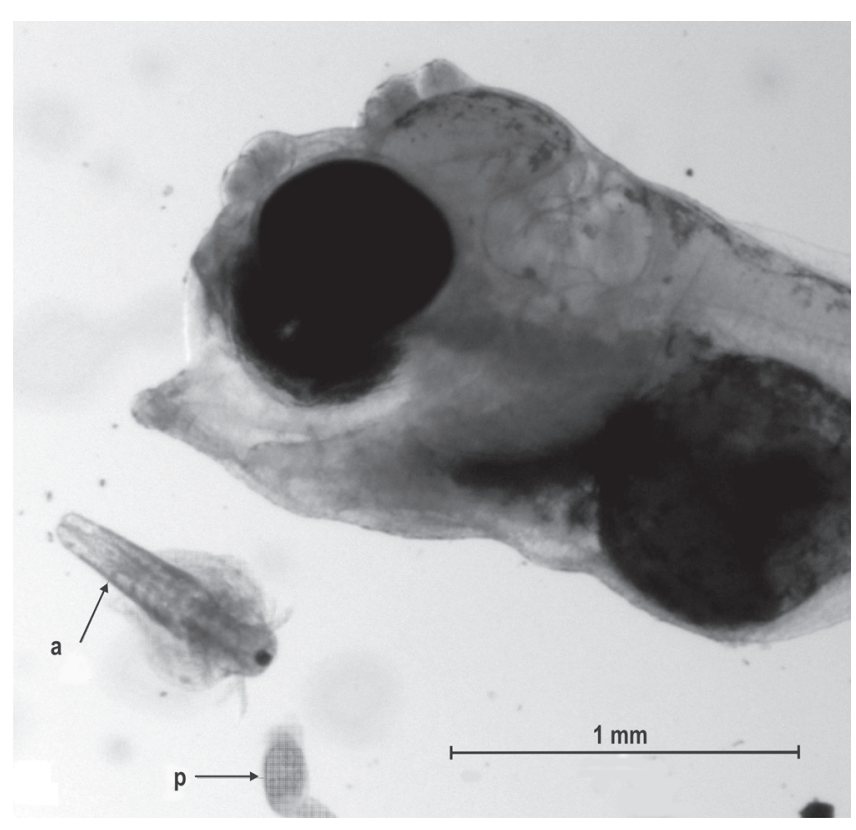

Fig. 8. Feeding larva; a - artemia nauplii, p - protozoan.
As shown by our experience, incubation of the angelfish embryos in the Weiss jars resulted in a very high survival rate, but, as reported by aquarium keepers, this manner of producing angelfish offspring has both advantages and disadvantages. When a breeder comes across a pair of spawners unable to care for the eggs of hatching larvae, the larvae can be kept in the Weiss jars to ensure survival. However, such fry do not learn appropriate brood care behaviours. As a result, when they lay their own eggs in the future, they will be unable to care for them.

The $\mathrm{pH}$ of water is one of the key factors determining the proper process of angelfish (Pterophyllum scalare) embryonic development and maintaining water parameters at the appropriate level is a prerequisite for ensuring proper embryogenesis. The ratio of surviving juveniles incubated in Weiss apparatus is comparable to the survival ratio under the care of the parents: both of these methods may be considered equally acceptable for breeding, provided that the fish whose early ontogeny took place in the Weiss Apparatus will not reproduce, because they do not develop the instinct of care for offspring under such conditions. Mortality of angelfish larvae fed for the first days after hatching with Artemia salina nauplius was higher than those fed with protozoa and rotifers, which suggests that breeders should choose the latter type of feed, if possible.

\section{Literature Cited}

Abdolbaghian, S., S. Jamili \& A. Matinfar. 2010. The effect of temperature and diet on the degrees of specific growth rate percentage (SGR \%) and weight growth (WG \%) of angel fish fry Pterophyllum scalare. Journal of Fisheries and Aquatic Science, 5: 311-315.

Al Adhami, M. A. \& Y. W. Kunz. 1976. Haematopoietic centres in the developing angelfish, Pterophyllum scalare (Cuvier and Valenciennes). Wilhelm Roux's Archives of Developmental Biology, 179: 393-401.

Aldridge, D. C. 1999. Development of European bitterling in the gills of freshwater mussels, Journal of Fish Biology, 54: 138-151.

Axelrod, H. \& B. Walker. 2000. The guide to owning angelfish. New Jersey, TFH Publication, Inc., 64p.

Barlow, G. W. 1991. Mating systems among cichlid fishes. Pp. 173190. In: Keenleyside, M. H. A. (Ed.). Cichlid fishes: behaviour ecology and evolution. London, Chapman \& Hall, 404p.

Barrows, F. T., R. E. Zitzow \& G. A. Kindschi. 1993. Effect of surface water spray, diet and phase feeding on swim bladder inflation, survival, and on production of intensively reared larval walleyes. Progressive Fish-Culturist, 55: 224-228.

Bennemann, R. \& I. Pietzsch-Rohrschneider. 1978. The morphology of the cement gland apparatus of larval Pterophyllum scalare Cuv. \& Valenciennes) (Cichlidae, Teleostei). Cell and Tissue Research, 193: 491-501.

Bonislawska, M., A. Korzelecka \& A. Winnicki. 1999. Morphomechanical aspects of the embryonic development of sun bleak (Leucaspius delineatus Heck.). Folia Universitatis Agriculturae Stetinensis. 192, Piscaria, 25: 13-23.

Brauner, C. J. \& A. L. Val. 1996. The interaction between $\mathrm{O}_{2}$ and $\mathrm{CO}_{2}$ exchange in the obligate air breather, Arapaima gigas, and the facultative air breather, Liposarcus pardalis. Pp. 101-110. In: Val, A. L., V. M. F. Almeida-Val \& D. J. Randall (Eds.). 
Physiology and Biochemistry of the Fishes of the Amazon. Manaus, Brasil, INPA, 402p.

Cacho, M. S. R. F., S. Chellappa \& M. E. Yamamoto. 2006. Reproductive success and female preference in the Amazonian cichlid angel fish, Pterophyllum scalare (Lichtenstein, 1823). Neotropical Ichthyology, 4: 87-91.

Cacho, S. R. F., M. E. Yamamoto \& S. Chellapa.1999. Comportamento reprodutivo do acará bandeira, Pterophyllum scalare (Osteichthyes, Cichlidae). Revista Brasileira de Zoologia, 16: 653-664.

Caneppele, D., R. M. Honji, A. W. Hilsdorf \& R. G. Moreira. 2009. Induced spawning of the endangered Neotropical species Steindachneridion parahybae (Siluriformes: Pimelodidae). Neotropical Ichthyology, 7: 759-762.

Chellapa, S., M. E. Yamamoto, S. R. F. Cacho \& F. A. Huntingford. 1999. Prior residence, body size and dynamics of territorial disputes between male freshwater angelfish. Journal of Fish Biology, 55: 1163-1170.

Coleman, R. 2002. Cichlid Research homepage. Cichlid egg size data. Available from: http://cichlidresearch.com/ eggtab3.html\#Ptychochromines (Date of Access: 2004).

Formicki, K., I. Smaruj, J. Szulc \& A. Winnicki. 2009. Microtubular network of the gelatinous egg envelope within the egg ribbon of European perch, Perca fluviatilis L. Acta Ichthyologica et Piscatoria, 39: 147-151.

Frank, S. 1984. Akvaristika. Pp. 196-199. Prace Praha, 342p. [in Czech].

Froese, R. \& D. Pauly. FishBase. World Wide Web electronic publication. 2010. Available from: www.fishbase.org, version (11/2010), (April/2010).

Gonzalez, R. J. \& R.W. Wilson. 2001. Patterns of ion regulation in acidophilic fish native to the ion-poor, acidic Rio Negro. Journal of Fish Biology, 58: 1680-1690.

Groppelli, S., R. Pennati, C. Sotgia \& F. de Bernardi. 2003. Cement gland apparatus of the angelfish Pterophyllum scalare (Teleostei, Cichlidae): Functional morphology in comparison with adhesive organs of other Chordata. Italian Journal of Zoology, 70: 133-139.

Honji, R. M., P. H. Mello, B. C. Araújo, J. A. Rodrigues-Filho, A. W. S. Hilsdorf \& R. G. Moreira. 2011. Influence of spawning procedure on gametes fertilization success in Salminus hilarii Valenciennes, 1850 (Teleostei: Characidae): Implications for the conservation of this species. Neotropical Ichthyology, 9: 363-370.

Kahl, W., B. Kahl \& D. Vogt. 1997. Kosmos-Atlas Aquarienfishe: über 750 Süsswasser-Arten. Stuttgart, Franckh-Kosmos Verlags, 288p.

Korzelecka-Orkisz, A., M. Bonislawska, D. Pawlos, J. Szulc, A. Winnicki \& K. Formicki. 2009. Morphophysiological aspects of the embryonic development of tench (Tinca tinca (L.)). Electronic Journal of Polish Agricultural Universities, 12: \#21. http://www.ejpau.media.pl/volume12/issue4/art-21.html.

Korzelecka-Orkisz, A., I. Smaruj, D. Pawlos, P. Robakowski, A. Tañski, J. Szulc \& K. Formicki. 2010. Embryogenesis of the stinging catfish, Heteropneustes fossilis (Actinopterygii: Siluriformes: Heteropneustidae). Acta Ichthyologica et Piscatoria, 40: 187-197.

Korzelecka, A. \& A. Winnicki. 1998. Peculiarities of embryogenesis in Scardinus erythrophthalmus L. Electronic Journal Polish Agricultural Universities, 1, 1, ser. Fish. http:// www.ejpau.media.pl/volume1/issue1/fisheries/art-01.html. £ugowska, K. 2007. Rozwój larwalny skalara (Pterophyllum scalare) w hodowli laboratoryjnej. [Ontogenesis of angelfish (Pterophyllum scalare) in laboratory breeding]. Komunikaty Rybackie, 4: 31-33. [in Polish].

Meijide, F. J. \& G. A. Guerrero. 2000. Embryonic and larval development of a substrate-brooding cichlid Cichlasoma dimerus (Heckel, 1840) under laboratory conditions. Journal of Zoology, 252: 481-493.

Mills, D. 1993. Angelfish. Pp. 123-125. In: Mills, D. Aquarium Fish. , London, A Dorling Kindersley Book, 304p.

Pérez, E., F. Díaz \& S. Espinac. 2003. Thermoregulatory behaviour and critical thermal limits of the angelfish Pterophyllum scalare (Lichtenstein) (Pisces: Cichlidae). Journal of Thermal Biology, 28: 531-537.

Reebs, S. 2001. Fish behaviour in the Aquarium and in the Wild. Pp. 143-145. Ithaca-London, Comstock Publishing Associates, a division of Cornell University Press, 159p.

Riehl, R. \& S. Appelbaum. 1991. A unique adhesion apparatus on the eggs of the catfish Clarias gariepinus (Teleostei, Clariidae). Japanese Journal of Ichthyology, 38: 191-197.

Sarma, S.S.S., J. Amador López-Rómulo \& S. Nandini. 2003. Larval feeding behaviour of blind fish Astyanax fasciatus (Characidae), black tetra Gymnocorymbus ternetzi (Characidae) and angel fish Pterophyllum scalare (Cichlidae) fed zooplankton. Hydrobiologia, 510: 207-216.

Sieniawski, A. 2004. Skalary. [Angelfish]. Tarnów, Wydawnictwo AMBRA, 138p. [in Polish].

Smith, C. \& P. Reay. 1991. Cannibalism in teleost fish. Reviews in Fish Biology and Fisheries, 1: 41-64.

Szulc, J. 2007. Ultrastrukturalne osobliwos'ci budowy oslon jajowych ryb na tle warunków ich naturalnego rozrodu. [Ultrastructural peculiarities of egg shells in relation the condition of to their natural reproduction.] Unpublished Ph.D. Dissertation, Agricultural University of Szczecin, Poland. [in Polish], 73p.

Tañski, A., A. Korzelecka, M. Bonis ${ }^{3}$ awska, A. Winnicki \& K. Formicki. 2000. New data on morphomechanical changes during embryogenesis of pike (Esox lucius L.). Folia Universitatis Agriculturae Stetinensis, 214, ser. Piscaria, 27: 207-213.

Val, A. \& V. M. F. Almeida-Val. 1995. Fishes of the Amazon and their environments. Physiological and biochemical features. Heidelberg, Springer Verlag, 224p.

Winnicki, A. \& A. Korzelecka. 1997. Morphomechanical aspects of the development of the bleak (Alburnus alburnus L.). Acta Ichthyologica et Piscatoria, 27, 2: 17-27.

Winnicki, A., A. Korzelecka \& A. Tañski. 1998. New data on breeding and early ontogenesis of three-spined stickleback (Gasterosteus aculeatus L.). Archives of Polish Fisheries, 6: 115-122.

Yamamoto, M. E., S. Chellappa, M. S. R. F. Cacho \& F. A. Huntigford. 1999. Mate guarding in an Amazonian cichlid, Pterophyllum scalare. Journal of Fish Biology, 55: 888-891.

Zalachowski, W. 1997. Ryby [Fish]. Pp. 223-224. Warszawa, Wydawnictwo Naukowe PWN, 528p. [in Polish].

Submitted March 21, 2011

Accepted May 30, 2012

Published September 28, 2012 